Final Report

DE-FG02-88ER 13978

\title{
Organic Geochemical and Tectonic Evolution of the Midcontinent Rift System
}

\author{
J. M. HAYeS AND L. M. PRATT \\ Biogeochemical Laboratories, Department of Geological Sciences \\ Indiana University, Bloomington, Indiana 47405
}

A. H. KNOLL

Department of Organismal and Evolutionary Biology

Harvard University, Cambridge, Massachusetts 02138

\section{DISCLAIMER}

This report was prepared as an account of work sponsored by an agency of the United States This report was prepared as an account of thork Government. Neither the Unity express or implied, or assumes any legal liability or responsiemployees, makes any warranty, express or implited, or accuracy, completeness, or usefulness of any information, apparatus, product, or bility for the accuracts process disclosed, or represents thercial product, process, or service by trade name, trademark, ence herein to ancers not necessarily constitute or imply its endorsement, recommanufacturer, or otherwise doe United States Government or any agency thereof. The views mendation, or favoring by the United herein do not necessarily state or reflect those of the United States Government or any agency thereof. 
This project was funded for 36 months and three annual progress reports have already been submitted. The first, 20 pages of text +14 figures, was submitted together with the request for the second year of funding. The second, 14 pages of text +5 figures and 2 tables, was submitted together with the request for the third year of funding. The third, 18 pages of text +16 figures and 2 large tables, was submitted with the proposal for continuation of this work. That proposal, entitled "Biogeochemical studies of Earth's evolution from late Proterozoic to early Paleozoic time," L. M. Pratt, principal investigator, J. M. Hayes and S. C. Brassell co-investigators, was declined.

\section{Publications}

Pratt, L. M., Summons, R. E. and Hieshima, G. B., 1991, Sterane and triterpane biomarkers in the Precambian! Nonesuch Formation, North American Midcontinent Rift: Geochimica et Cosmochimica Acta 55, 911-916.

Butterfield, N., A. Knoll, and K. Swett (1990) A bangiophyte red alga from the Proterozoic of arctic Canada. Science 250: 104-107.

Hieshima, G. B. and Pratt, L. M., 1991, Sulfur/carbon ratios and extractable organic matter of the Middle Proterozoic Nonesuch Formation, North American Midcontinent rift: Precambrian Research, 54, 65-79.

Asmerom, Y., S. Jacobsen, A. Knoll, N. Butterfield, and K. Swett (1991) Strontium isotopic variations in Neoproterozoic seawater: implications for crustal evolution. Geochimica et Cosmochimica Acta 55: 2883-2894.

Pratt, L. M., and Davis, C. L., 1992. Intertwined fates of metals, sulfur, and organic carbon in black shales, in Pratt, L. M., Comer, J. B., and Brassell, S. C., eds., Geochemistry of Organic Matter in Sediments and Sedimentary Rocks. SEPM Short Course 27, p. 1-27. 
R. E. Summons and J. M. Hayes. Principles of molecular and isotopic biogeochemistry. pp 83-94 in J. W. Schopf and C. Klein (eds.) The Proterozoic Biosphere, a Multidisciplinary Study. Cambridge University Press, 1992.

Butterfield, N. J. (1992) Studies in Proterozoic Paleobiology from Spitsbergen and Arctic Canada. Unpublished Ph.D. Thesis, Harvard University.

H. Strauss, D. J. DesMarais, J. M. Hayes, and R. E. Summons. Concentrations of organic carbon and maturities and elemental compositions of kerogens. pp 95-100 in Schopf and Klein, op. cit.

H. Strauss, D. J. DesMarais, J. M. Hayes, and R. E. Summons. The carbon-isotopic record. pp 117-128 in Schopf and Klein, op. cit.

J. M. Hayes, I. B. Lambert, and H. Strauss. The sulfur-isotopic record. pp 129-132 in Schopf and Klein, op. cit.

Mauk, J. L. and Hieshima, G. B., 1992. Organic matter and copper mineralization at White Pine, Michigan, U.S.A. Chemical Geology, 99, 189-211.

H. Strauss, D. J. DesMarais, J. M. Hayes, and R. E. Summons. Proterozoic organic carbon - its preservation and isotopic record. pp. 203-211 in M. Schidlowski (ed.) Early Organic Evolution: Implications for Mineral and Energy Resources. Springer Verlag, (1992).

J. W. Collister, R. E. Summons, E. Lichtfouse, and J. M. Hayes. An isotopic biogeochemical study of the Green River Oil Shale. Advances in Organic Geochemistry 1991, Proceedings of the 15th Intemational Meeting on Organic Geochemistry, 19, 265-276.

D. A. Zaback, L. M. Pratt, and J. M. Hayes. Transport and reduction of sulfate and immobilization of sulfide in marine black shales. Geology, 21, 141-144.

Kenig, F., Hayes, J. M., Popp, B. N., and Summons, R. E. (in press) Isotopic biogeochemistry of the Oxford Clay Formation, Callovian, U. K. J. Geol. Soc. 
Butterfield, N. and Chandler, F. W. Paleoenvironmental and biostratigraphic distribution of Proterozoic microfossils, with an example from the Agu Bay Formation (Fury and Hecla Group), Baffin Island. Palaeontology, in press.

Knoll, A. H. Archean and Proterozoic fossils, IN: J. Jansonius and C. McGregor, eds., Palynology and Stratigraphy, AASP Press, in press.

Lichtfouse, E., Albrecht, P., Béhar, F., and Hayes, J. M. (submitted) A molecular and isotopic study of the organic matter from the Paris Basin, France. Geochimica et Cosmochimica Acta.

\section{Overview of Scientific Themes and Accomplishments}

The progress reports and publications cited above provide relatively detailed information regarding the work supported by this grant. Funds were spent mainly to support investigations focused on the Nonesuch Shale and related Proterozoic sedimentary strata. Fossils from the Nonesuch were not sufficiently well-preserved to warrant preparation of a separate report describing their characteristics, but diverse geochemical investigations were carried to completion. In particular, the availability of high quality samples collected as part of this project allowed the first definitive characterization of cyclic biomarkers from the Nonesuch Shale (Pratt et al., 1991), studies of carbon-sulfur relationships were carried through (Hieshima and Pratt, 1991) and their results generalized (Pratt and Davis, 1992), and organic-metal relationships examined (Mauk and Hieshima, 1992).

A portion of the funds flowed to support of other projects via two pathways: (i) summer salary for the principal investigator and (ii) fractional support for two post-doctoral research associates not working on samples from the Mid-Continent Rift. By the former mechanism, DOE funds contributed significantly to preparation of an extensive review of Proterozoic biogeochemistry (Summons and Hayes, 1992; Strauss et al., 1992a, 1992b, 1992c; Hayes et al., 1992) and to development of a new model for fractionation of sulfur isotopes in sedimentary systems (Zaback et al., 1993). Work by postdoctoral associates that can be credited entirely or in significant part to DOE funds is summarized in 
reports of compound-specific isotopic studies of the Green River Oil Shale (Collister et al., 1992) and Paris-Basin sediments (Lichtfouse et al., submitted), and a systematic study of the organic geochemistry of the Oxford Clay (Kenig et al., in press).

\section{Addendum}

After the third annual report had been submitted to DOE, additional notes were received from Professor Knoll, providing an overview of the Harvard component of this project:

Knoll had two tasks in this program. The first was to examine thin sections and palynological preparations of Nonesuch Shale samples in order to evaluate paleontological evidence for the sources and timing of organic carbon deposition. The second was a broader assignment to evaluate the degree to which fossils and chemostratigraphic signatures can constrain the biological origins and stratigraphic correlations of late Proterozoic sedimentary successions. Such tools are essential in any attempt to investigate the petroleum potential of Proterozoic rocks.

Nonesuch shale samples from both Michigan and Iowa contain scattered but well-preserved microfossils that constrain sources for organic matter. A large majority of the fossils are the probable reproductive cysts of eukaryotic phytoplankton, mostly spheroidal vesicles 20 to more than $100 \mu \mathrm{m}$ in diameter. Filamentous cynobacteria and, possibly, eukaryotic algae occur, but constitute a minor portion of preserved assemblages. The preserved fossil assemblage is similar to Mesoproterozoic assemblages found in the Belt Supergroup, Moitana; the Roper Group, Australia; the Billyakh Group, northern Siberia; and a newly discovered assemblage in the Agu Bay Formation, arctic Canada (Butterfield and Chandler, in press).

The Nonesuch and Agu Bay assemblages stand in strong contrast to the microfossil assemblages we have recovered from the younger Proterozoic Shaler Group; here a rich and varied assemblage of prokaryotes, eukaryotic protists, and sea weeds is preserved (Butterfield, 1992). Shaler fossils can be compared with similarly diverse assemblages of broadly comparable age in Spitsbergen (the Svan- 
bergfjellet Formation) and Siberia (the Lakhanda, Miroyedikha, and Derevny formations). The older assemblages also stand in contrast with the ca. 1000 Ma old Hunting Formation, Arctic Canada, which contains what may be the oldest evidence for modern algae - red algal fossils that compare closely with members of the extant family Bangiophyceae (Butterfield et al., 1990). Taken together the Nonesuch, Shaler, Hunting and other assemblages support the hypothesis of a major episode of eukaryotic diversification ca. $1000 \mathrm{Ma}$ ago. Prior to this time, eukaryotic primary producers must have been physiologically primitive (and now extinct) algae whose abundance in ecosystems is poorly constrained by analogies with the present oceans. Cyanobacteria were major primary producers in a wide range of marine environments. After $1000 \mathrm{Ma}$, diversifying red green and chromophyte algae contributed significantly to primary production in all save microbial mat communities in restricted environments. It bears mention that such mat communities remained significant potential sources of buried organic matter until the end of the Proterozoic, necessitating exploration strategies that differ from those commonly employed for younger rocks (Knoll, in press).

As in Phanerozoic basins, petroleum exploration in Proterozoic rocks requires tools for stratigraphic correlation. In Neoproterozoic $(<1000 \mathrm{Ma})$ rocks, biostratigraphy is possible, and it is aided significantly by $\mathrm{C}$ and $\mathrm{Sr}$ isotopic chemostratigraphy. New data from the Shaler Group contribute to the construction of $\mathrm{C}$ and $\mathrm{Sr}$ isotopic curves for Neoproterozoic time, making possible much improved chronostratigraphy for this time interval. (Asmerom et al., 1991; Hayes et al., ms. in preparation).

\section{Disclaimer}

DOE's support does not constitute an endorsement by DOE of the views expressed in the final report. 

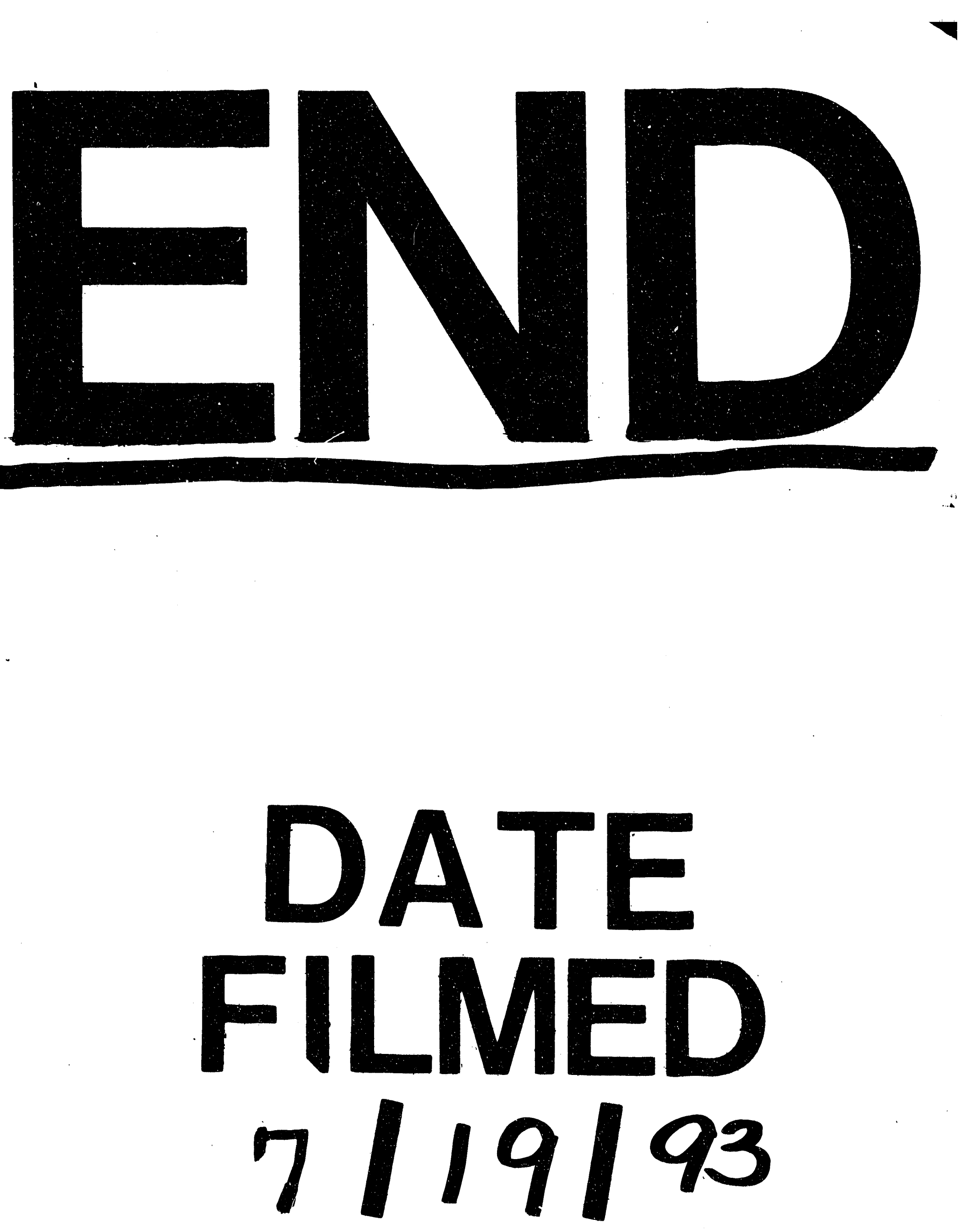
